G. Golovko, Ye. Chaika, M. Luchko

Poltava National Technical Yuri Kondratyuk University, Poltava,Ukraine

\title{
UPDATE THE COMPUTER NETWORK AT THE ENTERPRISE «MAGNETIK CORPORATION»
}

\begin{abstract}
The subject matter of the article is the process of matching the optimal solutions for improving the local computer network. The purpose is to update the existing local computer network of the enterprise Magnetic Corporation. The task is to justify the opportunity for using various types of network applications and components. Having applied knowledge about the characteristics of each viewing items' properties, the obtained results are used to enter them into a single network. To summarize the conclusions: in order to maximize network productivity the local computer network with a dedicated server was selected, i.e. star topology, that has led to an increase in network security and an increase in the speed of fixing problems in any workstation without affecting the overall network health.
\end{abstract}

Keywords : network, topology, network operation system, network software.

\section{Introduction}

Perhaps the modern Internet is the largest engineering system created by a person. It contains millions of connected computers, communication lines and switches; with billions of users connected through various data communication devices. Let's take into account that the Internet is so large and has that many different components, however in the meanwhile, is it possible to understand how it works? Are there any leading principles and structure that can serve as the basis for understanding an incredibly large and at the same time a difficult system? But if so, might be interesting to learn computer networks? However, for all these questions, we are surely answering YES! In fact, our purpose in this article is to offer a modern introduction to the fast-growing area of computer networks, highlighting the principles that are needed to understand both today's and tomorrow's technologies. Studying the computer networking general principles will help you to deal quickly with any specific network technology in the future. However, the well-known expression "Knowledge of several principles frees from memorizing a set of facts" should not be taken literally a good specialist, of course, should know a lot of details and facts. Principles knowledge allow to systematize this private statements, link them with one another in a coherent system and thereby use it more consciously and efficiently. Of course, the principles studying before the specific technologies studying is not an easy task, therefore, in this article we will consider the general computer network aspects.

We will organize our computer networks review in such way. After introducing basic terminology and some aspects, at first we will consider the basic hardware components that make up the network. We will also start with the network periphery and overview the end systems and network applications that run on the network. Then we explore the computer network core by analyzing the communications and switches that transmit data. We are also exploring access networks and physical media that connect end systems to the network core.

That is, different varieties of computer network construction and their problematics will be investigated.

\section{Analysis of common network building options}

Historically, the main purpose of integrating computers into a network was the resources sharing: computer users connected to the network, or applications that run on these computers, being able to automatically access various resources of other computers on the network.

In order to connect it is necessary that they have been provided with external interfaces. The interface - in a broad sense - is formally determined logical and / or physical boundary between the interacting independent objects. The interface specifies the parameters, procedures, and the objects interaction characteristics. Interfaces are divided into physical and logical interfaces.

The physical interface is determined by a set of electrical connections and signal characteristics. Usually it is a connector with contacts' set, each of that has a specific purpose, for example, it can be a group of contacts for data transmission and data synchronization contacts. A pair of connectors is linked by cable, consisting of a wires set, each of them connects the corresponding contacts. In such cases, talking about the line or channel creation, the connection between two devices.

The logical interface is an information messages set of a certain format, which are exchanged between two devices or two programs, as well as a rules set defining exchange logic of these messages. The most commonly used interfaces are computer to computer and computer-peripheral device.

Computer-to-computer interface allows two computers to share information. it It is implemented with a pair on each side:

- a hardware unit, called a network adapter, or a network interface card (Network Interface Card, NIC);

- a network interface card driver, is a special program that controls the network interface card operation.

A computer interface is a peripheral device that allows a computer to control a peripheral device operation. This interface is implemented:

- from the computer side - an interface card and a peripheral device driver similar to the network interface card and its driver; 
- from the peripheral device side - the peripheral device controller, is usually a hardware device, receives data from the computer, for instance, information bytes that needs to be printed on paper [1].

The need for access a remote device - users might have arise the most various applications: text editor, graphic editor, database management system. Obviously, that the duplication in each of the functions common applications to all of them in organizing the separated tasks execution is excessive.

The most efficient is the approach in which functions are excluded from applications and executed in the form of a specialized software modules pair (client and tasks server).

Summarizing this approach in relation to other shared resources types, we will provide the following definitions:

A client is a module designed for the request messages formation and transmission to the remote computer resources from various followed by receiving the results from the network and transferring them to the relevant applications.

A server is a module that constantly expects to come from network a customer request arrival and, upon a request acceptance, tries to serve it, as a rule, with the local operating system participation; one server can serve several clients requests at once (one by at a time or simultaneously). Each service is associated with a specific network resources type. Thus the client and server modules that implement remote access to the devices form a network service. [1]

The computer's operating system is often described as an interconnected system programs set that provides efficient computer resources control (memory, processor, external devices, files, etc.), and also provides the user with a convenient interface for working with computer hardware and application development.

Speaking of the network operating system, we obviously need to expand the managed resources boundaries beyond one computer. The network operating system is the computer's operating system, which, in addition to managing local resources, provides users and applications efficient and convenient access to network informational and other computers hardware resources. Remote access to network resources is provided by:

- network services;

- transporting messages facilities over the network (in the simplest case, network interface cards and their drivers).

Therefore, it is necessary that these modules have been added to the operating system so that it could be called networked. Operating system determines its position in the overall range of network operating systems due to how much network services and services are offered by the operating system to end users, applications and network administrators. In addition to network services, the network operating system should include software communication (transport) tools that provide messages transmission, exchanged between client and server parts of network services, with hardware communication tools. The tasks of communication between computers on the network are carried out by drivers and protocol modules. They perform functions such as message generation, splitting messages into parts (packets, frames), converting computer names into numeric addresses, duplicating messages in case of loss, determining the route in a complex network. Both network services and carriers can be integral (embedded) operating system components or exist as separate software products. A typical network operating system has a large set of drivers and protocol modules, but the user, generally, has the ability to supplement this standard set with programs he needs. The decision on how to implement clients and the network service servers, as well as drivers and protocol modules, is adopted by developers taking into account a variety of reasons: technical, commercial, and even legal. The network service can be represented in the operating system with either both (client and server) parts or only one of them [1].

Also, the enterprise network equipment plays an important role. This information must be taken into account when creating a computer network in an enterprise.

A LAN switch is a device designed to connect multiple computer network hosts within a single segment: Switch Zyxel GS1900-24E; Data transfer rate: 1000 Mbps; Connectors: 24xRJ-45.

Twisted pair is a network cable type, with one or more pairs of isolated conductors twisted together (with a small number of turns per unit length) to reduce reciprocal movements when transmitting a signal and coated with a plastic sheath. The cable is connected to network devices using the RJ-45 connector. It supports data transmission at a distance of about 100 meters.

RJ-45 is a physical interface that is commonly used to connect computer networks using a twisted pair over a network switch, or when creating a network from two computers to one another through a network card.

In accordance with the customer requirements, the marketing search for the necessary hardware and software of the local computer network was carried out (table 1,2) and the estimated total project cost (table 3).

\section{Table 1 - The cost of network equipment}

\begin{tabular}{|l|c|c|c|}
\hline \multicolumn{1}{|c|}{ Name } & Amount & $\begin{array}{c}\text { Cost per 1 } \\
\text { unit, UAH }\end{array}$ & $\begin{array}{c}\text { Full price, } \\
\text { UAH }\end{array}$ \\
\hline LAN Switch & 3 & 4955 & 14865 \\
\hline Cable & $500 \mathrm{~m}$ & 12 & 6000 \\
\hline Connector RJ-45 & 150 & 2,50 & 375 \\
\hline Total & & & 21240 \\
\hline
\end{tabular}

Table 2 - Software cost

\begin{tabular}{|l|c|c|c|}
\hline \multicolumn{1}{|c|}{ Name } & $\begin{array}{c}\text { Amo- } \\
\text { unt }\end{array}$ & $\begin{array}{c}\text { Cost per 1 } \\
\text { unit, UAH }\end{array}$ & $\begin{array}{c}\text { Full price, } \\
\text { UAH }\end{array}$ \\
\hline $\begin{array}{l}\text { Microsoft Windows 10 } \\
\text { Enterprise }\end{array}$ & 1 & 7800 & 7800 \\
\hline $\begin{array}{l}\text { Microsoft Offise 2016 } \\
\text { (boxed version) }\end{array}$ & 30 & 7000 & 210000 \\
\hline $\begin{array}{l}\text { Microsoft Windows Server } \\
\text { 2019 Standart }\end{array}$ & 1 & 25899 & 25899 \\
\hline 1C Accounting for Ukraine & 8 & 6690 & 53899 \\
\hline Total & & & 2970219 \\
\hline
\end{tabular}


Table 3 - Cost of the local network

\begin{tabular}{|l|c|}
\hline \multicolumn{1}{|c|}{ Constituent } & Cost, UAH \\
\hline Software & 297219 \\
\hline Network equipment & 21240 \\
\hline Hardware & 648570 \\
\hline Total & 967029 \\
\hline
\end{tabular}

There are many characteristics associated with the traffic transfer through physical channels.

- The proposed load is the data stream coming from the user to the network input. The proposed load can be characterized by the speed of data stream into the network in bits per second (or kilobits, megabytes, etc.).

- Data flow rate is the actual data flow speed that has passed through the network. This speed may be less than the proposed load speed, as the data in the network may be distorted or lost.

- Communication channel capacity, also called bandwidth, which represents the maximum possible information flow rate over a channel.

The specificity of this characteristic is that it reflects not only the physical medium parameters of transmission, but also the features of the chosen transmitting discrete information method in this medium. For example, the fullness of the communication channel in the Ethernet network on an optical fiber is $10 \mathrm{Mbps}$. This speed is extremely possible for combining Ethernet and optical fiber technology. Thus, fast Ethernet technology provides data transfer over the same optical fiber with a maximum speed of $100 \mathrm{Mbps}$, and Gigabit Ethernet technology $1000 \mathrm{Mbps}$. The transmitter of the communication device must operate at a rate equal to the bandwidth of the channel. This speed is sometimes called the bit rate of transmitter. Bandwidth - this term can be misleading because it is used in two different values. First, using it can characterize the transmission medium. Secondly, the term "bandwidth" is used synonymously with the term communication link capacity [2].

While transferring information from a computer to a computer information must be transmitted in two directions. So, it's necessary to understand that even when you simply receive information or transmit it, the information exchange goes from both directions. Namely, the main stream of data is created which is of interest to the recipient receiving the receipt information. However, an inverted information flow is also formed. Physical communication links are divided into several types depending on whether they can transmit information in both directions or not.

- The duplex channel provides simultaneous information flow in both directions. A two-way channel can consist of two physical environments, each of which is used to transmit information only in one direction. It is possible when one medium serves for the simultaneous transmission of counter flows, in this case, additional methods are used to separate each stream from the total signal.

- The simplex channel allows to transmit information only in one direction [2].

The more computers one network connects, the more difficult it is to work with it. That is, if you decide to combine multiple computers into one network, you need to pre-determine the configuration and network topology.

There is a large number of topologies for building a network, and the most popular ones are the ring topology and star topology.

Ring topology is a topology in which each computer is connected by communication lines to two others: it receives information from one, and transfers it to another. Each communication line has only one transmitter and one receiver. An important feature of the "ring" is that each computer restores (retransmits, amplifies) the signal coming to it, that is, acts as a repeater. The signal attenuation throughout the "ring" is not as important as the attenuation between the neighboring computers of the "ring". The ring networks sizes reach tens of kilometers, which significantly exceeds other topologies. There is no clearly distinguished host in the "ring" topology, all computers can be the same and equal. The "ring" topology usually has high resistance to overload, provides reliable work with large information flows transmitted over the network, there are usually no conflicts in it, nor is it a mandatory central subscriber that can be overwhelmed by large information flows [3].

The "star" topology is a topology with clearly defined host, to which all other subscribers connect. The entire information exchange goes exclusively through a host computer, which thus has more load, so it cannot deal with anything other than the network. It is clear that the host subscriber network equipment should be more complex than the peripheral subscribers' equipment. In this case, it is not necessary to speak about the subscribers' equality. As a rule, the host computer is the most powerful, and it is entrusted with all the functions of managing the exchange. Conflicts in the "star" network topology essentially are impossible, because management is fully centralized, there is nothing to confront. If we talk about the stability of the star concerning to the computers failures, the peripheral computer failure does not affect the functioning of the remaining network part, but any host computer failure makes the network completely unusable. Therefore, special measures should be taken to increase the reliability of the host computer and its network equipment. Any cable breakdown or short circuit in the "star" topology violates the exchange with the only one computer, and all other computers can normally continue to work [3].

The central topology element is a passive wire, to which several computers are connected according to the scheme. The main advantages of this topology are its simplicity, low cost budget and easy nodes connection to the network. The disadvantages are low reliability (any defect in the wire immediately brings the entire network out of order). At the same time, small networks, as a rule, have a typical topology - a star, a ring, or a common bus. The largest networks are characterized by polyface networks between computers. In such networks, it is possible to identify individual arbitrarily connected fragments that have a typical topology, so they are a mixed network topology [2]. After analyzing all aspects and parameters of each of the network elements, we came to a common conclusion 
on optimal equipment. All possible ways of creating networks and their characteristics (including the best and worst sides) have been examined and provided. So, this article is, an innovation for a person who just begins getting acquainted with the networks.

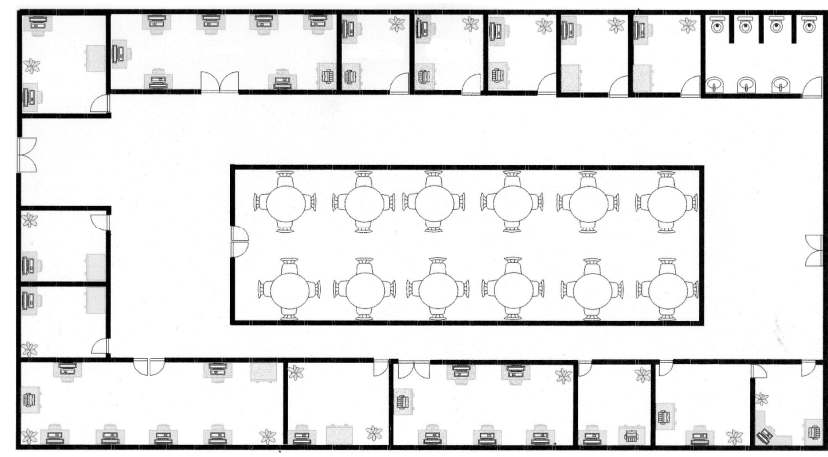

Fig. 1. Placement of hardware for selection

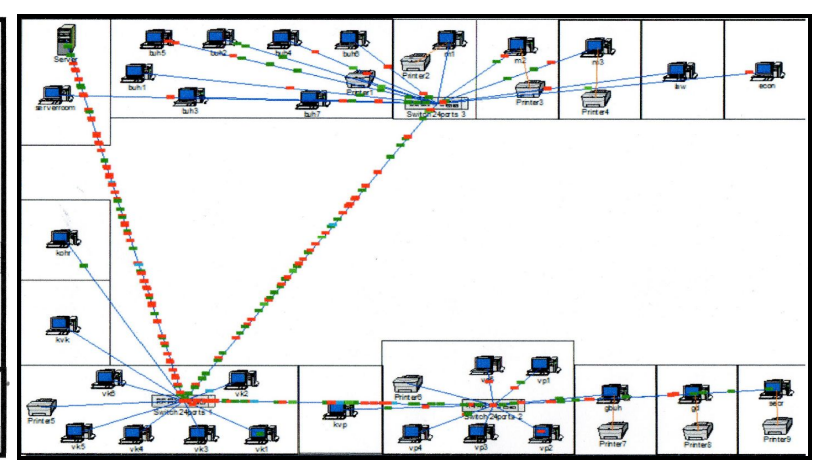

Fig. 2. Start the LAN work

\section{Conclusions}

In this paper, all possible types of network applications and components were identified and the most optimal process for updating and improving the computer network at the "Magnetik Corporation" enterprise was chosen.

Also, with the introduction of a new local computer network, the possibility of choosing from the
Also, all products characteristics that are required to create a local network will be recommended hereinafter. Including software cost evaluation and hardware (Fig. 1, 2). most widespread local networks was analyzed and having come to a conclusion that the local computer network topology of the star is the most optimal option for this enterprise. The article analyzes and points out that the implementation of this computer network also increases the network security, and significantly increases the speed of fixing the emerging problems in any workstation without affecting the overall network performance.

REFERENCES

1. V_Olifer_N_Olifer_Kompyuternye_seti_Printsipy_tekhnologii_protokoly_2016.pdf

2. Kompyuternye_seti_Niskhodyasch_podkhod_Kurouz.pdf

3. Топологія мережі. [Електронний ресурс]. - Режим доступу: ahttps:/studfiles.net/preview/5263810/page:2/

4. Cisco_CCNA_ICND2_200-101_Ofitsialnoe_rukovodstvo_po_podgotovke_k_ekzamenam.pdf

5. NetCracker Professional 3.1 portable. [Електронний ресурс]. - режим доступу: https://www/twirpx.com/file/1314986/

Рецензент: д-р техн. наук, проф. К. С. Козелкова, Державний університет телекомунікацій, Київ Received (Надійшла) 21.01.2019 Accepted for publication (Прийнята до друку) 13.03.2019

\section{Оновлення комп'ютерної локальної мережі для підприємства «Корпорація Магнетік»}

\section{Г. В. Головко, Є. А. Чайка, М. А. Лучко}

Предметом вивчення в статті є процес підбору оптимальних рішень що до вдосконалення локальної комп'ютерної мережі. Метою є оновлення існуючої локальної комп'ютерної мережі підприємства "Корпорація Магнетік". Завдання: обгрунтувати можливість застосування різних видів мережевих додатків та комплектуючих. Застосувавши знання про характеристики властивості кожного з оглядових предметів. Отримані результати використати для занесення всього до єдиної мережі. Висновки: за для максимальної продуктивності мережі було обрано: локальну комп'ютерну мережу 3 виділеним сервером, тобто топологію - зірка, що привело до підвищення безпеки мережі та підвищення швидкості виправлення виникаючих проблем в будь-якій робочій станції не впливаючи на загальну працездатність мережі.

Ключов і слов а: мережа, топологія, мережева операційна система, мережеве програмне забезпечення.

\section{Обновления компьютерной локальной сети для предприятия «Корпорация Магнэтик»}

\section{Г. В. Головко, Е. А. Чайка, М .А. Лучко}

Предметом изучения в статье является процесс подбора оптимальных решений для совершенствования локальной компьютерной сети. Целью является обновление существующей локальной компьютерной сети предприятия "Корпорация Магнэтик". Задача: обосновать возможность применения различных видов сетевых приложений и комплектующих. Применив знания о характеристиках свойства каждого из смотровых предметов. Полученные результаты использовать для занесения всего к единой сети. Выводы: для максимальной производительности сети была избрана: локальная компьютерная сеть с выделенным сервером, то есть топологию - звезда, что привело к повышению безопасности сети и повышения скорости исправления возникающих проблем в любой рабочей станции не влияя на общую работоспособность сети.

Ключевы е слов а: сеть, топология, сетевая операционная система, сетевое программное обеспечение. 